\title{
Determining textural and geochemical element characteristics of seafloor sediment using multivariate analysis along the Simeulue sub-basin, Indonesia
}

Rudarsko-geološko-naftni zbornik

(The Mining-Geology-Petroleum Engineering Bulletin) UDC: $551.1 / .4 ; 551.3 ; 551.46$

DOI: $10.17794 / \mathrm{rgn} .2020 .4 \cdot 7$

Original scientific paper

\author{
Septriono Hari Nugroho; Purna Sulastya Putra \\ Research Centre for Geotechnology, Indonesian Institute of Sciences (LIPI), Indonesia 40135
}

\begin{abstract}
The Simeulue sub-basin is situated off north-western Sumatra between the outer arc and the mainlands. The sediment and geochemical element characteristics of basins are the important sedimentology variables to recognize the process of sediment deposition. However, the characteristics of the sediment and the geochemical elements in the Simeulue subbasin have not been well explained. This study aims to investigate the textural and geochemical elements characteristics of marine sediments and the distribution of these two variables to determine the sedimentary facies in the Simeulue sub-basin. Samples were taken from various depths in the sub-basin and collected during the 2017 Expedition of "Widya Nusantara" by using the "Baruna Jaya VIII" Research Vessel. The grain size trend analysis showed that the middle part of the basin was dominated by mud, while the edge of the basin near the island (mainland) was mostly dominated by coarser sediments. A geochemical element analysis was performed on each sample to observe the origin of the sediments. The results of these two analyses were subjected to multivariate statistics. This approach was selected because it is appropriate for determining the sedimentary facies and the depositional environments. Based on the multivariate analysis, the sedimentary facies in the Simeulue sub-basin was divided into five facies with similar sediment characteristics and depositional environments. These facies were deposited in the environment with low to medium energy.
\end{abstract}

\section{Keywords:}

sediment; grainsize; geochemical; multivariate analysis; Simeulue.

\section{Introduction}

Granulometric analysis using Grain Size Trend Analysis (GSTA) is one of the proxies to determine the physical properties and sediment texture that are important for sediment transport and deposition study (Nugroho and Putra, 2018). Grain size is the most important property as it shows the sediment transport dynamics, history, provenance and depositional environment in recent and past times (e.g. Folk and Ward, 1957; Friedman, 1979; Blott and Pye, 2001; Dickhudt et al., 2011). Previous studies used the statistical parameters of the sediment grain (mean, sorting, skewness, kurtosis) to classify the depositional environment (e.g., Friedman, 1961; Folk, 1966; Visher, 1969; Ashley, 1978; McCave, 1984; Syvitski, 1991; Medina et al., 1994; Martins et al., 1997; Bobertz and Harff, 2003; Francke et al,. 2013). Statistical parameters were calculated in phi or $\mathrm{mm}$ units and the accuracy of the results depends on the accuracy of the plot (Wachecka-Kotkowska and Kotkowski, 2011). There are several methods to interpret the depositional environment based on the grain size, and the multivariate statistical method is one of the most reliable (Boggs,

Corresponding author: Hari Nugroho

sept006@lipi.go.id
1995). The multivariate statistical method is a powerful tool for analyzing and interpreting the depositional environment as it combines several different variables and avoids a single sample analysis (Chambers and Upchurch, 1979). This method was considered to be more effective as it facilitates the measurement and loss of efficiency produced (Nugroho et al., 2018). Some studies used multivariate methods in determining sedimentary facies in Southern Kuwait, Queensland (Australia) and Southern Utah (USA), as well as the Tarakan sub-basin (Indonesia) by Gischeler and Lomando (2005), Thoms et al. (2007), Allen and Johnson (2010), and Nugroho et al. (2018), respectively.

The geochemical analysis of marine sediments aims to determine the composition of the chemical elements of a material that can be utilized in tracing source materials and linkages with other units in an area (Irzon, 2018). Brouwer (2010) stated that the analysis of geochemical elements using XRF-scanners is very useful to support data on the chemical content of a material. The analysis is used to support the interpretation of the source or origin of the sediments. The geochemical approach has been widely used for research in oceanography, paleoclimate, and environmental change. The elements that can be recorded by XRF analysis include the main elements, which are Aluminum (Al), Calcium 


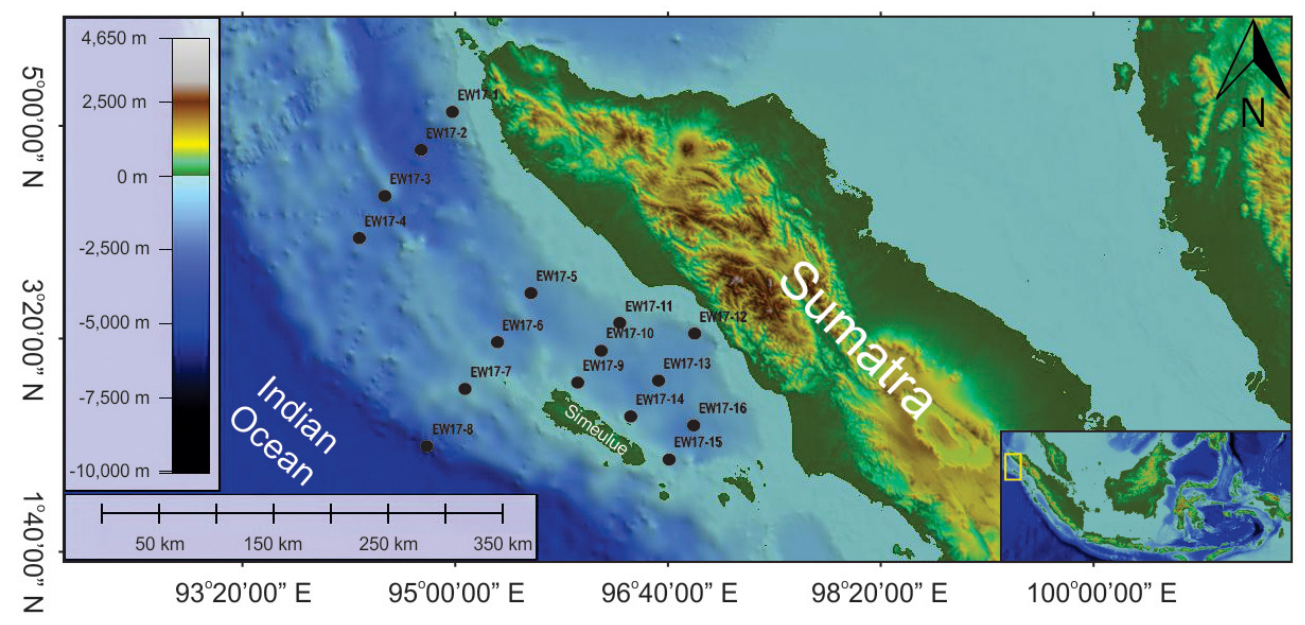

Figure 1: The research location was situated in the Simeulue sub-basin, at various depths in the sub-basin.

(Ca), Iron/Ferrum (Fe), Magnesium (Mg), Manganese (Mn), Silicon (Si), Sodium (Na), Titanium (Ti), and Potassium (K). The secondary elements are Barium (Ba), Cerium (Ce), Cobalt (Co), Copper ( $\mathrm{Cu})$, Chromium (Cr), Gallium (Ga), Lanthanum (La), Niobium (Nb), Nickel (Ni), Rhodium (Rh), Rubidium (Rb), Scandium (Sc), Strontium (Sr), Uranium (U), Vanadium (V), Yttrium (Y), Zirconium (Zr) and Zinc (Zn) (Gosseau, 2009). However, according to Rothwell and Croudace (2015) the elements commonly used to reconstruct certain environmental conditions are Calcium $(\mathrm{Ca})$, Iron (Ferrum / Fe), Strontium (Sr), Potassium (K), and Titanium (Ti). Sampurno et al (2018) and Nugroho and Putra (2019) used elemental analysis to determine the depositional environment of marine sediments from the waters of West Bangka and the beaches of Sumba Island, respectively.

Studies of the distribution of seafloor sediment have also been conducted in Indonesia by Nugroho and Basit (2014); Wisha et al. (2017); Putra and Nugroho (2017); and Nugroho et al. (2018). Their research showed the grain size distribution was strongly influenced by the provenance and sedimentary processes. The previous study by Wisha et al. (2017) only performed a surface sediment study of Simeulue Cut Island, a small island off the western coast of Simeulue Island. The study has determined the distribution of surface sediment in the coastal area based on the tidal current conditions. Nevertheless, the characteristics of seafloor sediments in the Simeulue sub-basin is still unexplained. Recently, the application of multivariate statistics in textural analysis was used for a sedimentary facies study in Indonesia. Nugroho et al. (2018) used a multivariate technique to determine the sedimentary facies in the sub-basin of Tarakan, Kalimantan. This study successfully classifies the sedimentary sub-facies that match the depositional pattern. However, no geochemical analyses were obtained in the study. A study on sediment provenance based on a combination of grain size and geo- chemical characteristics has never been evaluated in Indonesia.

This study explains the relationship between sediment distributions, transportation processes and deposition environments of sedimentary at the Simeulue subbasin. The research is important to provide explanations about the transportation process, deposition and provenance. Comprehensive studies in the offshore and deep sea areas are also essential to support new deep-water exploration in Indonesia. This paper features a combination of proxies, GSTA and geochemical using multivariate analysis. This multi-proxies study is a new approach for seafloor sediment characterization in this area.

\section{Study area}

The study area is situated in the Simeulue sub-basin. The survey was conducted in December 2017, where the samples were collected from 16 stations in Simeulue waters (see Figure 1). However, two stations (EW17-7 and EW17-8) were not successful in obtaining the seafloor sediment samples, so only 14 stations were used in this study. As this study will be the first that combines multi-proxy approaches in the Simeulue sub-basin area, these fourteen samples are adequate to obtain general seafloor sediment characteristics in Simeulue waters. A box corer was installed in the Baruna Jaya VIII Research Vessel to collect sediment samples from various bathymetry. In this study, two analytical methods are used, such as granulometry and geochemical analysis. Statistical analysis is used to divide facies based on their similarity in textural and geochemical characteristics.

The Simeulue sub-basin was selected as it has a strategic location both geographically and geologically. It is situated in the subduction zone between the Indian and Australian plates. The distribution of seafloor sediment is also influenced by oceanographic factors. Measured currents showed that the surface current moved relative- 
ly fast $(0.7-1.4 \mathrm{~m} / \mathrm{s})$ while moving towards the Northwest, while at a depth of 100 meters or deeper, the current moved slower to the southeast $(0.1-0.6 \mathrm{~m} / \mathrm{s})(\mathrm{see}$ Table 1). Simeulue waters have a seasonal variation in the regional flow that causes a change in the water mass transport patterns, and this in turn causes upwelling on the Sumatra coast (Putri et al., 2017). The water mass is influenced by the temperature and salinity (see Figure 2). Wyrtki (1961) stated the water temperature was affected by the seasonal change cycle. The temperature was also influenced by the intensity of the sunlight, bathymetry and terrestrial influx (Sidjabat, 1974). The water depth was divided into three layers: the surface, thermocline and inner layer. The thermocline layer is a layer where the temperature decreased rapidly. Surinati (2009) measured the water temperature of Simeulue with the following results: a depth of $0-50$ meters (surface) was $29-30^{\circ} \mathrm{C}$, a depth of $50-200$ meters (thermocline) was $29-30^{\circ} \mathrm{C}$, which was stabilized at a depth of 200 meters, and deeper water was $<13{ }^{\circ} \mathrm{C}$. The 2017 Widya Nusantara Expedition (EWIN) reported similar water temperature results; the water temperature dropped by $2{ }^{\circ} \mathrm{C}$ at each depth level and the surface temperatures were $28.5-30{ }^{\circ} \mathrm{C}$ (Putri et al., 2017). The expedition measured the thermocline layer that starts at $70-80$ meters and ends at $300-500$ meters.

Table 1: Current measured in Simeulue waters (Putri et al., 2017)

\begin{tabular}{|l|l|l|l|}
\hline No. & Depth $(\mathrm{m})$ & Velocity $(\mathrm{m} / \mathrm{s})$ & Current Direction \\
\hline 1 & Surface & $0.7-1.4$ & Northwest \\
\hline 2 & 100 & $0.3-0.6$ & Southeast \\
\hline 3 & 150 & $0.3-0.5$ & Southeast \\
\hline 4 & 200 & $0.1-0.3$ & Southeast \\
\hline
\end{tabular}
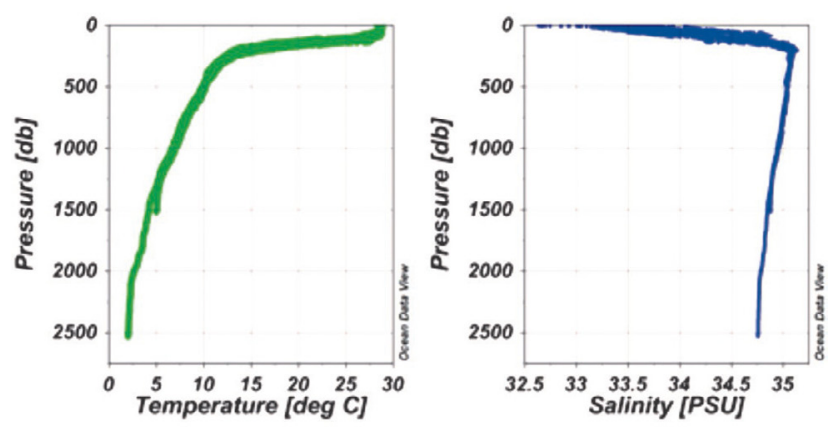

Figure 2: Temperature and salinity profile in Simeulue waters (Putri et al., 2017).

The salinity profile has a similar result with the temperature (see Figure 2). As measured by Surinati (2009), the salinity in the surface and thermocline layers have 33.1 - 33.5 PSU and 34 PSU, respectively. At 250 meters, the salinity reaches up to $35.13 \mathrm{PSU}$, which is the highest salinity in this area, while the inner layer is relatively stable. This indicates that the changes in salinity level were not affected by the current or other factors.
Furthermore, the results of the EWIN 2017 (Putri et al., 2017) showed that the surface salinity ranges from 32.7 to $33.9 \mathrm{PSU}$, then reaches a maximum of $35.2 \mathrm{PSU}$ at 200 meters and decreases again to $34.7 \mathrm{PSU}$ at $1000 \mathrm{me}-$ ters. The stations in the Indian Ocean show a higher salinity (33.5 - 34 PSU), while ones between Simeulue Island and Sumatera Island coast have a lower salinity (32 - 33 PSU). This low salinity condition is likely due to the presence of fresh water input from the mainland Sumatra and Simeulue Island.

\section{Methods}

Grain size analysis was conducted in the Sedimentology Laboratory at Research Center for Geotechnology LIPI in Bandung, Indonesia. The Malvern Mastersizer 2000 was used to measure the grain size, as it is capable of measuring the grain size from 0.02 to $2000 \mu \mathrm{m}$. Grain size analysis was performed to obtain the sediment types and distribution. Furthermore, the data was processed using Gradistat software to calculate the statistical parameters, i.e. mean, sorting, skewness and kurtosis (Blott and Pye, 2001).

Marine seafloor sediment characteristics are usually described using grain size data. To map the grain size distribution of sediments, seafloor sediment samples were first collected by a field survey and information about grain sizes was then produced through experiments in the laboratory. From grain size data, sediment fractions, as indicated by the percentage of sand, silt, and clay, are generally obtained and the sedimentary facies are then classified by applying certain classification schemes, such as Shepard's rule (Poppe and Eliason, 2008). Several kriging algorithms can be applied to the mapping of seafloor sedimentary facies using grain size data. The first possible approach is the kriging indicator which can be applied directly to categorical data (Journel, 1983), because the target attribute for mapping marine seafloor sediments is categorical information. In this approach, sample data is first classified as sedimentary facies based on their grain size fraction and the transformation of the indicator is then applied. Spatial correlation information from the indicator-coded binary data for each sediment class is used for the kriging indicator. The grainsize and bathymetry data was processed and interpolated using the Kriging algorithm from the Surfer 15.0 Golden Software. These methods are commonly used in facies characterizations (Bobertz and Harff, 2003; Nugroho et al., 2018).

Geochemical element analysis was carried out using a Thermo Scientific X-ray fluorescence (XRF) Analyzer at the Resource Physics Laboratory at the Research Center for Geotechnology LIPI. The analysis results were obtained in parts per million (ppm). The elements used in this study are $\mathrm{Ca}, \mathrm{Fe}, \mathrm{Sr}, \mathrm{K}$ and $\mathrm{Ti}$, which were helping to analyze the origin of sediment supply. The elements of $\mathrm{Ti}$ and $\mathrm{Fe}$ are interpreted for terrestrial sedi- 
ment input (Dypvik and Harris, 2001; Mollier-vogel et al., 2013), and the elements of $\mathrm{Ca}$ and $\mathrm{Sr}$ are interpreted as the result of numerous biogenic processes, prediction of oxygen content, carbonate content and sea level changes (Langer, 2008; Croudace and Rothwell, 2015). The weathering intensity was interpreted using the elements of $\mathrm{K}$ and $\mathrm{Sr}$. Element $\mathrm{K}$ tends not to survive on the residue of weathering due to absorption or turning into clay, so a more intense weathering process will contain less K (Nesbitt et al., 1980). Moreover, the value of $\mathrm{Sr}$ also tends to be less resistant because it comes from plagioclase and pyroxene (Hemming et al., 2007).

The next step after the statistical parameters were obtained, was to create a bivariate plot. The goal of this method is to learn the correlations of statistical parameters which describe the depositional environment, sedimentary process and depositional energy (Nugroho et al., 2018). A complete model of depositional mechanism was presented in a CM diagram as illustrated in Passega (1964). The parameters of a CM diagram are $\mathrm{C}$ (the first percentile value) and $\mathrm{M}$ (median) plotted in micron. The $\mathrm{C}$ and $\mathrm{M}$ show an effect of the sorting sediment and turbulence process. A Stewart diagram (Stewart, 1958) was used to understand the sediment deposition process. The Stewart diagram has two parameters, median and sorting, which are plotted in phi values.

The Principle Component Analysis (PCA) and Cluster Analysis (CA) statistical methods for the combined textural sediment and geochemical data were used to determine the relationship between the sediment and facies characteristics within the basin (Jongman et al., 1995). The PCA was used to reduce the grain size distribution variable in all samples to a small number of key variables (Oyedotun et al., 2012). Besides determining the main factor, PCA also determined the correlation of each variable and the sediment parameters. The CA hierarchy using Euclidean distance and the mean correlation was applied to the distribution of grain size and geochemical elements to put a sediment sample in a group with similar sedimentology characteristics (Oyedotun et al 2012). The $C A$ was conducted using thirteen variables: bathymetry, sand percentage, mud percentage, mean grain size, standard deviation (sorting), skewness, kurtosis and median, as well as content of $\mathrm{Ca}, \mathrm{Sr}, \mathrm{K}, \mathrm{Ti}, \mathrm{Fe}$. In this study, single-linkage clustering was used to determine facies by calculating the similar or different sedimentary characteristics and geochemical elements between the closest cluster pairs. Single linkage is a hierarchical method that groups data based on the nearest neighbor or the maximum similarity between two or more data (Johnson and Wichern, 2007). This measure defines the distance between two groups as the minimum distance found between one case from the first group and one case from the second group (Yim and Ramdeen, 2015). The following Equation 1 is used to determine groups in the single linkage method (Johnson and Wichern, 2007):

$$
D_{(u v) w}=\min \min \left(D_{u w}-D_{v w}\right)
$$

where:

$D_{u w}, D_{v w}$ is the distance between the nearest neighbors of the group ( $\mathrm{U}$ and $\mathrm{W})$ and the group of $\mathrm{V}$ and $\mathrm{W}$, and vice versa.

Euclidean distance is used as a criterion for measuring similarity in grouping data in this study. Then the calculations are obtained by the distance matrix (Johnson and Wichern, 2007). The following Equation 2 is used to determine Euclidean distance:

$$
D_{i j}=\sqrt{\sum_{k=1}^{p}\left(a_{i k}-a_{j k}\right)^{2}}
$$

where:

$D_{i j}=$ the distance between the $\mathrm{i}$ - and $\mathrm{j}$ - objects

$a_{i k}=$ observation value of the $\mathrm{i}$ - object and k- variable

$a_{j k}=$ observation value of the $\mathrm{j}$ - object and $\mathrm{k}$ - variable

The clustering results can be seen visually in a tree diagram (dendogram). The vertical axis shows the distance where groups are combined and the horizontal axis shows the data identity number (Nosrati and van den Eeckhaut, 2012). Besides being used to show existing group members, a dendogram can also be used to determine the number of groups formed. The dendogram was built to describe the degree of similarity between multivariate objects. Moreover, all these statistical methods were processed by using the PAST - Paleontological Statistics Software - version 1.99.

\section{Results and Discussion}

\subsection{Textural Distribution}

In general, there are ten types of sediment identified in this study (see Table 2): coarse sand (CS), medium sand (MS), fine sand (FS), very fine sand (VFS), very coarse silt (VCST), coarse silt (CST), medium silt (MST), fine silt (FST), very fine silt (VFST) and clay (CL). The determination of sediment type is influenced by the percentage of grain size composition in a surface sediment. According to the composition, the seafloor sediment in the Simeulue sub-basin is dominated by silt, from fine to coarse silt (see Table 2).

Furthermore, sediment distribution also correlates to bathymetry conditions of the sampling location. In accordance with Tipsword et al. (1966), the bathymetry in the Simeulue sub-basin was classified to Upper bathyal $(200-500 \mathrm{~m})$, lower bathyal $(500-2000 \mathrm{~m})$, and abbyssal $(2000-2500 \mathrm{~m})$. As shown by the trend of mud and sand content, which are expanding the abundance of finer sediment into the deeper parts of the Simeulue subbasin (see Figure 3). When the bathymetry is relatively deeper, the sediment grain size became to relatively finer grain size, and vice versa. The medium silt sediment was dominant at bathymetry of more than 600 meters, while coarser sediments occurred at bathymetry of less than 
Table 2: Composition and sediment type in the Simeulue sub-basin

\begin{tabular}{|l|l|l|l|l|l|l|l|l|l|l|l|}
\hline Sample & CS & MS & FS & VFS & VCST & CST & MST & FST & VFST & CL & Name \\
\hline EW17-1 & 0.0655 & 0.3161 & 0.2551 & 0.0905 & 0.0483 & 0.0502 & 0.0599 & 0.0546 & 0.0335 & 0.0262 & MS \\
\hline EW17-2 & 0.0003 & 0.0168 & 0.0365 & 0.1123 & 0.1524 & 0.1654 & 0.1683 & 0.1581 & 0.1069 & 0.0831 & MST \\
\hline EW17-3 & 0.0000 & 0.0000 & 0.0000 & 0.0592 & 0.1885 & 0.2005 & 0.1800 & 0.1682 & 0.1143 & 0.0893 & CST \\
\hline EW17-4 & 0.0086 & 0.0264 & 0.0021 & 0.0154 & 0.1096 & 0.2411 & 0.2397 & 0.1726 & 0.1067 & 0.0778 & CST \\
\hline EW17-5 & 0.0000 & 0.0000 & 0.0078 & 0.0458 & 0.0880 & 0.1595 & 0.2256 & 0.2269 & 0.1443 & 0.1020 & FST \\
\hline EW17-6 & 0.0000 & 0.0000 & 0.0071 & 0.0592 & 0.1047 & 0.1712 & 0.2300 & 0.2133 & 0.1257 & 0.0889 & MST \\
\hline EW17-9 & 0.0019 & 0.0041 & 0.0089 & 0.0192 & 0.0592 & 0.1597 & 0.2470 & 0.2451 & 0.1512 & 0.1037 & MST \\
\hline EW17-10 & 0.0000 & 0.0019 & 0.0056 & 0.0360 & 0.0835 & 0.1741 & 0.2462 & 0.2287 & 0.1335 & 0.0905 & MST \\
\hline EW17-11 & 0.0191 & 0.0204 & 0.0582 & 0.1416 & 0.1627 & 0.1800 & 0.1719 & 0.1284 & 0.0688 & 0.0489 & CST \\
\hline EW17-12 & 0.0000 & 0.0000 & 0.0061 & 0.0209 & 0.0677 & 0.1801 & 0.2620 & 0.2375 & 0.1360 & 0.0896 & MST \\
\hline EW17-13 & 0.0000 & 0.0002 & 0.0085 & 0.0247 & 0.0724 & 0.1781 & 0.2553 & 0.2342 & 0.1360 & 0.0907 & MST \\
\hline EW17-14 & 0.0569 & 0.0879 & 0.1338 & 0.1684 & 0.1169 & 0.1203 & 0.1250 & 0.0978 & 0.0542 & 0.0379 & VFS \\
\hline EW17-15 & 0.0678 & 0.4049 & 0.3112 & 0.0567 & 0.0335 & 0.0277 & 0.0288 & 0.0291 & 0.0199 & 0.0203 & MS \\
\hline EW17-16 & 0.0000 & 0.0039 & 0.0126 & 0.0388 & 0.1125 & 0.2226 & 0.2522 & 0.1936 & 0.0997 & 0.0641 & MST \\
\hline
\end{tabular}

Grain size sediment type: CS: coarse sand; MS: medium sand; FS: fine sand; VFS: very fine sand; VCST: very coarse silt; CST: coarse silt; MST: medium silt; FST: fine silt; VFST: very fine silt; CL: clay

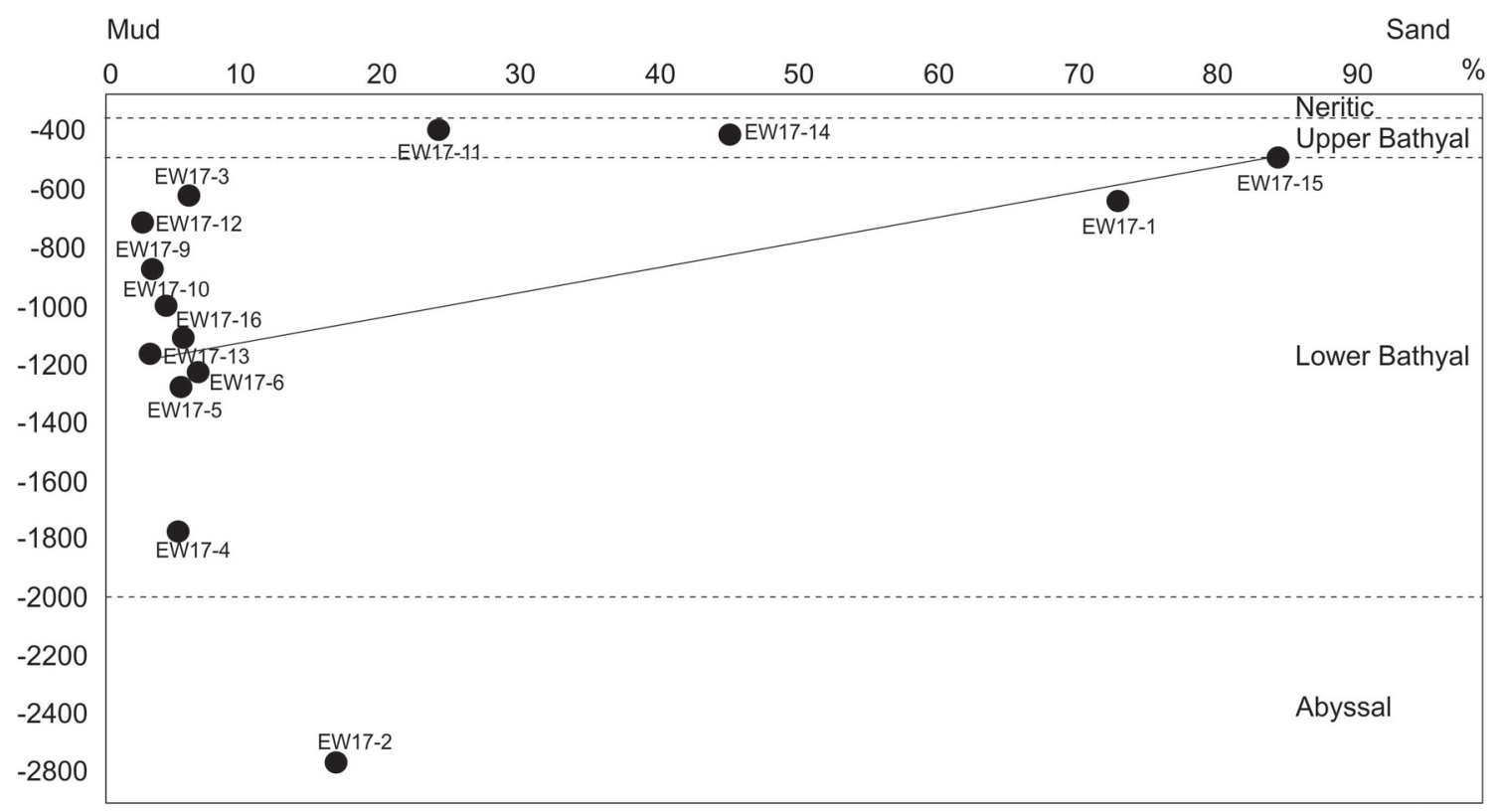

Figure 3: Sediment distribution correlates to the bathymetry of sampling location that shows the percentage of the sand composition of each sample

600 meters (see Figure 3). The spatial distribution of sediment composition shows increasingly coarser sediment towards the mainland (Sumatra and Simeulue Islands, Figure 4). On the other hand, the central part (Simeulue Strait) and towards to the deep ocean, the sediments were dominated by fine grained sediments (see Figure 4). This reflects the mainland is the provenance or source of the seafloor sediments in the Simeulue sub-basin. This result greatly correlates with the previous study in the Sumba Island (Putra and Nugroho, 2017) and Tarakan sub-basin (Nugroho et al., 2018). However the study in the Weda Bay shows a different result (Nugroho and Basit, 2014), where the sediment is coarser towards the deeper sea. This may be caused by complex currents in the Weda Bay. The GSTA values show an abundance of fine sediments along the Simeulue sub-basin. This also corresponds to low disturbances and low energy environments.

The textural attributes of sediments, including mean grain size, sorting, skewness and kurtosis are widely indicated to reconstruct the sediments in a depositional environment (Angusamy and Rajamanickam, 2006). The relationship between size parameters and the transport process/sedimentation mechanism has been studied in many modern and ancient sedimentary environments (Folk and Ward, 1957; Friedman, 1967; Visher, 1969; 


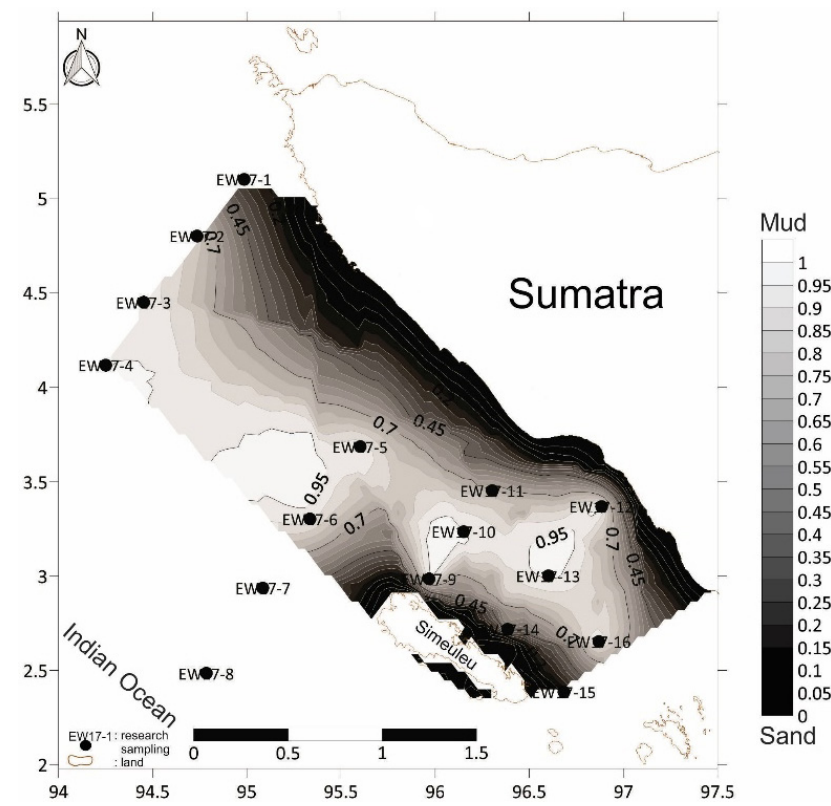

Figure 4: The seafloor sediment distribution map that shows that the sediment is coarser landward

Ramanathan et al., 2009; Anithamary et al., 2011). Table 3 shows parameters of statistical value of seafloor sediment in the Simeulue sub-basin. The difference in statistical value of seafloor sediments is influenced by variation in the morphological conditions at the study site. The mean grain size of samples varies from 2.432 to 7.027 phi. The majority of the sediment samples fall into the medium silt category. The sorting of sediment measured by standard deviation $(\sigma 1)$, shows that the values range between 1.513 and 2.480 phi. The standard deviation values are included in the poorly to very poorly sorting category. Sediment sorting in the Simeulue sub-basin is indirectly correlated with the bathymetry changes. However, the sorting changes in the location of the study were affected by the current (both speed and direction) as well as the source of sediments. This represents that sediment within poorer sorting is collected from the areas near Sumatra Island. The value of the 4th moment kurtosis ranges from 0.862 to 2,096 phi, including in leptokurtic to very leptokurtic kurtosis. The kurtosis value in this area is also influenced by the bathymetry. It indicates that the sediment distribution becomes platycurtic with an increase in bathymetry. The upper bathyal sediments are dominated by coarse silt to fine sand, poorly sorted, symmetrical to very fine skewed, and kurtosis values show platicurtic to very leptokurtic kurtosis. The middle bathyal sediments tend to be fine silt to very fine sand, poorly - very poorly sorted, symmetrical very fine skewed, and mesokurtic kurtosis. The study site is dominated by middle bathyal. The lower bathyal sediments are medium silt, very poorly sorted, symmetrical skewness and have platykurtic kurtosis. Skewness measures the asymmetry of the frequency distribution. Skewness values range between -0.025 and 0.593 phi, the symmetry of the samples varies from coarse skewed to very fine skewed. The skewness value is also related to depth. As can be seen from the skewness value, which is 0.212 in the shallower area and gradually decreases as the bathymetry decreases. This result is against the previous research by Putra and Nugroho (2017) where bathymetry did not affect the skewness value.

The sediment distribution in the seafloor of the Simeulue sub-basin is strongly influenced by the current pattern. Bascom (1951) identified that the sediment grainsize distribution has a positive relationship with wave energy. Surface current moves to the northwest, it correlates to the Indian Ocean current, where it moves to the west, then turns to the north when it hits Sumatra. The near shore sediment is influenced highly by the sediment from the mainland (Sumatra and Simeulue Islands), where it is transported by the river system and longshore current. This conclusion is also supported by the low salinity value which indicates the occurrence of freshwater influx (Putri et al., 2017).

Table 3: Parameters of statistical value of the seafloor sediments

\begin{tabular}{|l|l|l|l|l|l|l|}
\hline Sample & Water depth & Morphological unit & Mean (Phi) & Sorting (Phi) & Skewness (Phi) & Kurtosis (Phi) \\
\hline EW17-1 & 639 & Middle bathyal & 3.304 & 2.348 & 0.593 & 1.064 \\
\hline EW17-2 & 2590 & Lower bathyal & 6.102 & 2.073 & 0.019 & 0.893 \\
\hline EW17-3 & 628 & Middle bathyal & 6.406 & 1.801 & 0.128 & 0.862 \\
\hline EW17-4 & 1776 & Middle bathyal & 6.525 & 1.640 & 0.120 & 1.037 \\
\hline EW17-5 & 1277 & Middle bathyal & 6.853 & 1.727 & -0.025 & 1.048 \\
\hline EW17-6 & 1236 & Middle bathyal & 6.662 & 1.751 & -0.018 & 1.039 \\
\hline EW17-9 & 884 & Middle bathyal & 7.027 & 1.573 & 0.025 & 1.071 \\
\hline EW17-10 & 1009 & Middle bathyal & 6.820 & 1.631 & 0.008 & 1.059 \\
\hline EW17-11 & 407 & Upper bathyal & 5.553 & 2.060 & 0.007 & 0.950 \\
\hline EW17-12 & 725 & Middle bathyal & 6.909 & 1.513 & 0.057 & 1.038 \\
\hline EW17-13 & 1176 & Middle bathyal & 6.883 & 1.564 & 0.035 & 1.053 \\
\hline EW17-14 & 418 & Upper bathyal & 4.604 & 2.480 & 0.102 & 0.863 \\
\hline EW17-15 & 501 & Upper bathyal & 2.432 & 1.709 & 0.527 & 2.096 \\
\hline EW17-16 & 1116 & Middle bathyal & 6.468 & 1.586 & 0.050 & 1.059 \\
\hline
\end{tabular}




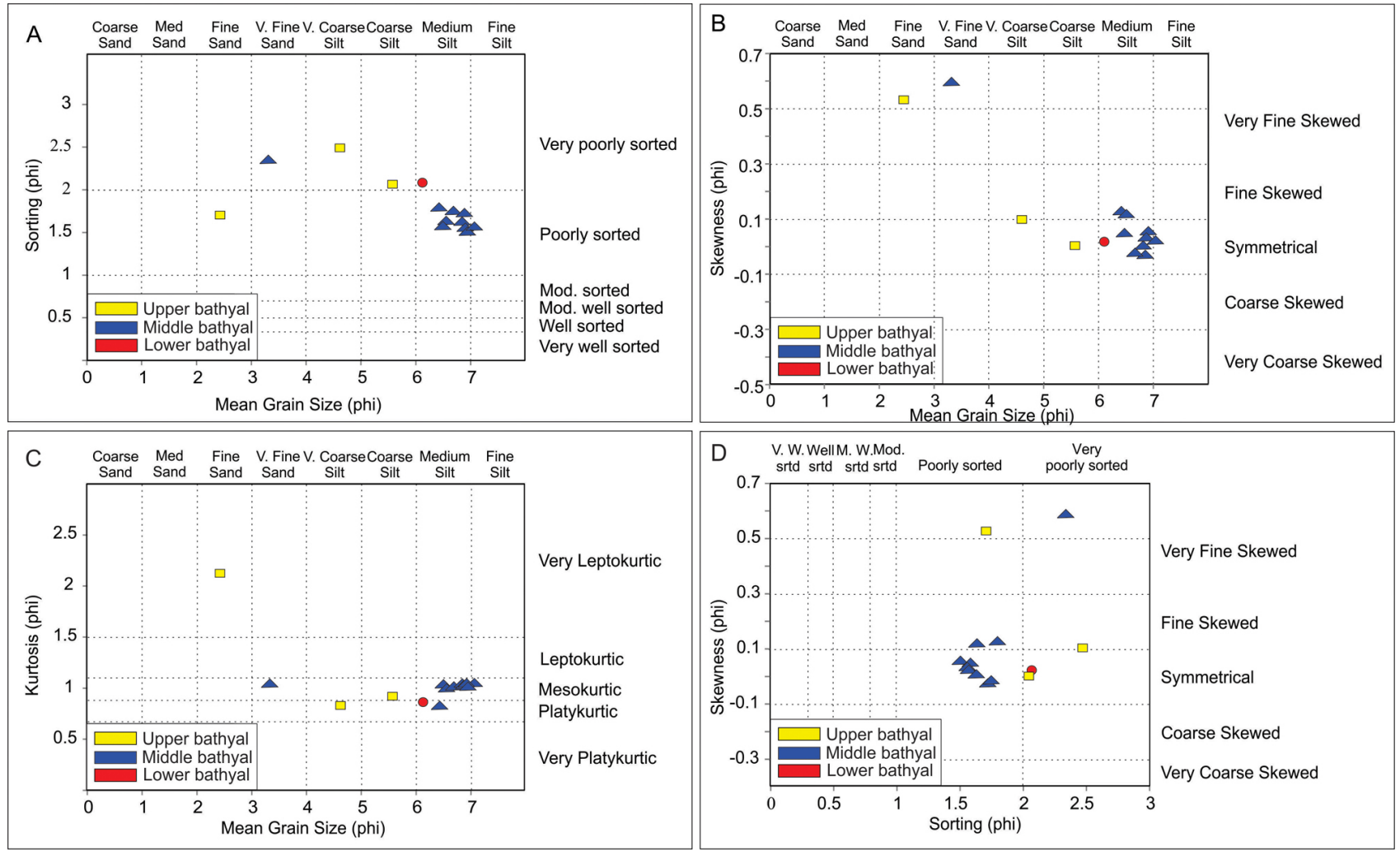

Figure 5: The statistical plot that describes the relationship between statistical parameters

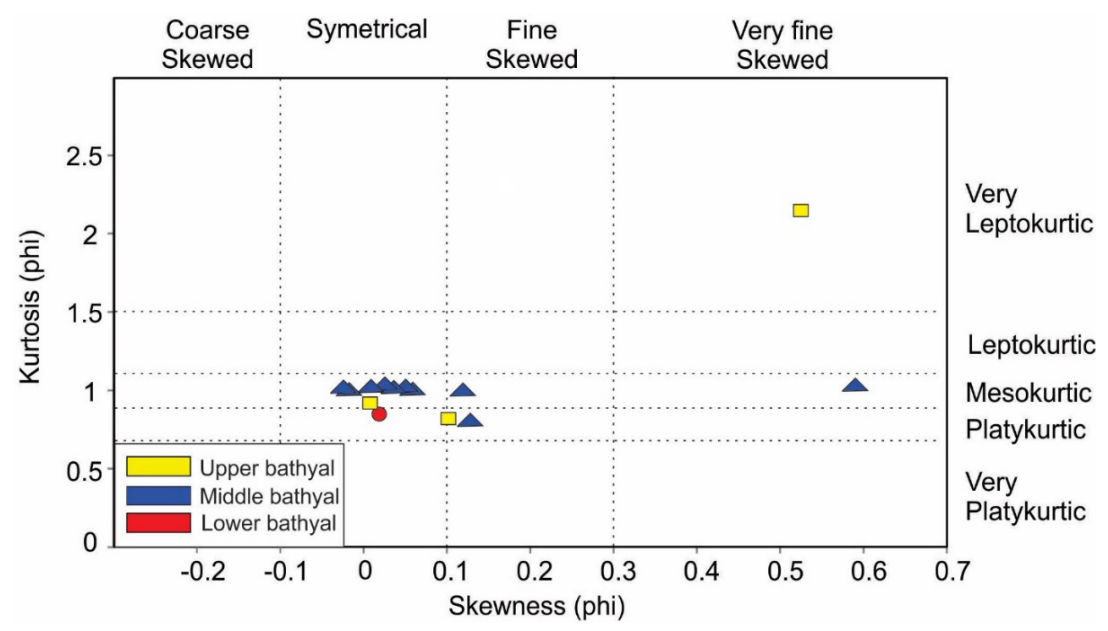

Figure 6: The relationship between skewness and kurtosis of the seafloor sediments

\subsection{Bivariate plots}

The bivariate plots have been used to represent the depositional environment, including the transportation sediment process and depositional mechanism. Figure 5a shows the relationship between mean grain size and sorting in the Simeulue sub-basin. As explained by Tucker (1988) mean grain size and sorting have some covariance. Griffiths (1967) mentioned a hydraulic control between the mean grain size and sorting; therefore, the finer sediments generally have the best sediment sorting in all sediment environment. In contrast, the
Simeulue sub-basin provides different evidence that fine-sized sediments are poorly sorted. This might be associated with significant changes in bathymetry in the study area. It reflects the samples from shallow areas are ranging from fine sand to coarse silt sediment, while the deep areas are dominated by poorly sorted medium silt. There is a clustering in medium silt and poorly sorted that is represented by sediment on the middle bathyal. Figure 5b illustrates the relationship between the mean and skewness. There is an obviously general trend for the skewness values to increase as mean grain size decrease in phi units. It explains the shape of grains are 


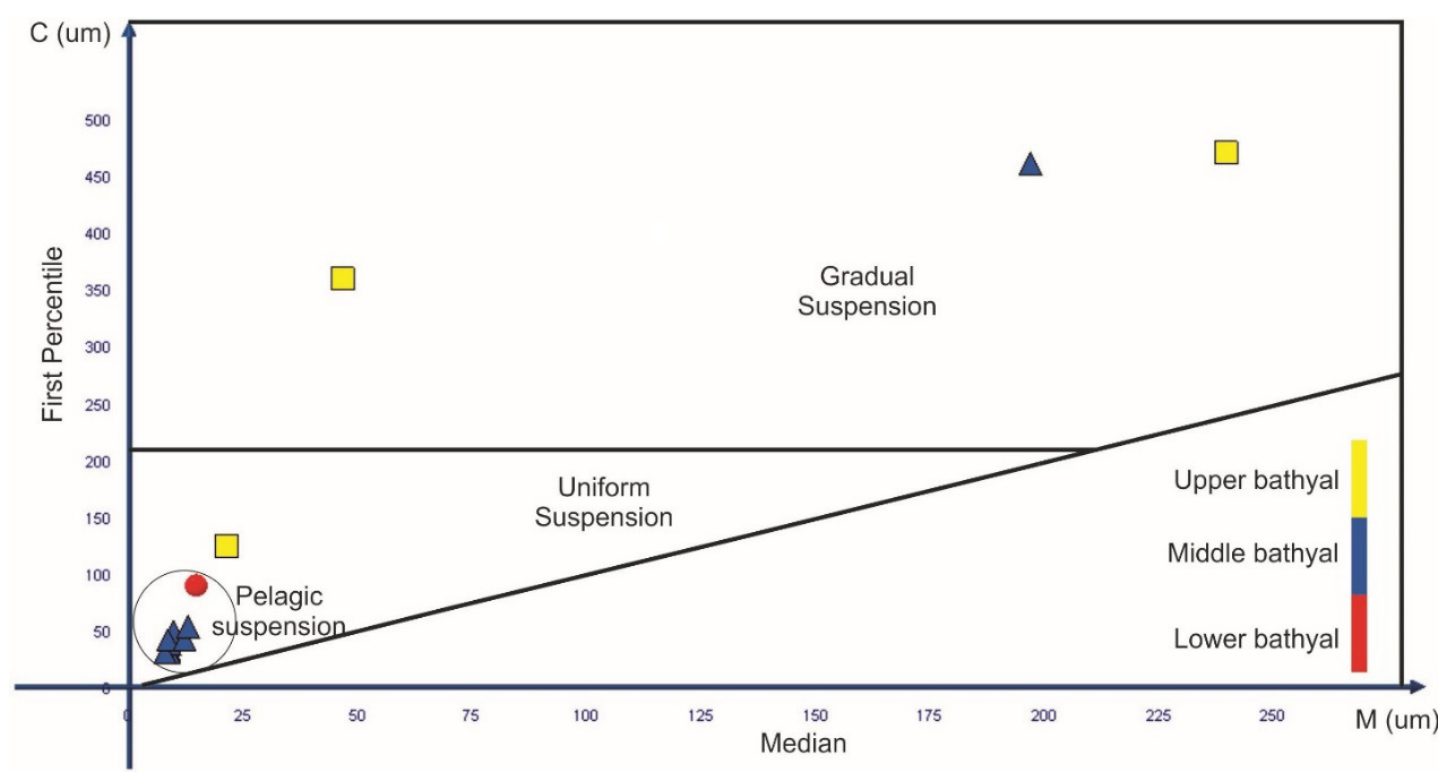

Figure 7: The relationship between $\mathrm{C}$ and $\mathrm{M}$, representing that the majority of the sediments were deposited as a pelagic suspension mechanism

more symmetrical by the medium silt in the middle bathyal. Figure 5c presents the relationship between the mean grain size and kurtosis. The sediments from the Simeulue sub-basin lie within the platykurtic to mesokurtic range. The value of kurtosis is also changed by different depths, the deeper bathymetry shows the value of kurtosis is getting smaller. It reveals the finer sediment in lower bathyal clustered in platykurtic to mesokurtic range. Figure 5d reveals the relationship between sorting and skewness in the Simeulue sub-basin seabed. Almost all sediment samples in the Simeulue sub-basin which are poorly sorted are mainly clustered around the near symmetrical to fine skewed range and have positive skeweness values. The plotting of skewness versus kurtosis is a powerful tool for interpretting the genesis of sediment, by quantifying the degree of normality of its size distribution (Folk, 1966). It is clear that most of the sediments from the Simeulue sub-basin lie within the positively skewed/platy- to lepto-kurtic field (see Figure 6). This suggests the dominance of a fine grain-size population, which gives a positive skewness.

\subsection{CM-plot and Stewart diagram}

In the present study, an attempt has been made to identify the modes of deposition of sediments of the Simeulue sub-basin by CM pattern. The C (first percentile value) and $\mathrm{M}$ (median) are plotted for phi values of the $\mathrm{C}$ and $\mathrm{M}$ obtained from the cumulative curve in microns (see Figure 7). The correlation between $\mathrm{C}$ and $\mathrm{M}$ has illustrated a turbulent process in the sedimentary deposition that contributes to the effect of sorting on the grain size. Most seafloor sediments in the Simeulue subbasin are deposited by the pelagic suspension mechanism, although some are gradually suspended (see Figure 7). That reflects a normal sedimentation mechanism

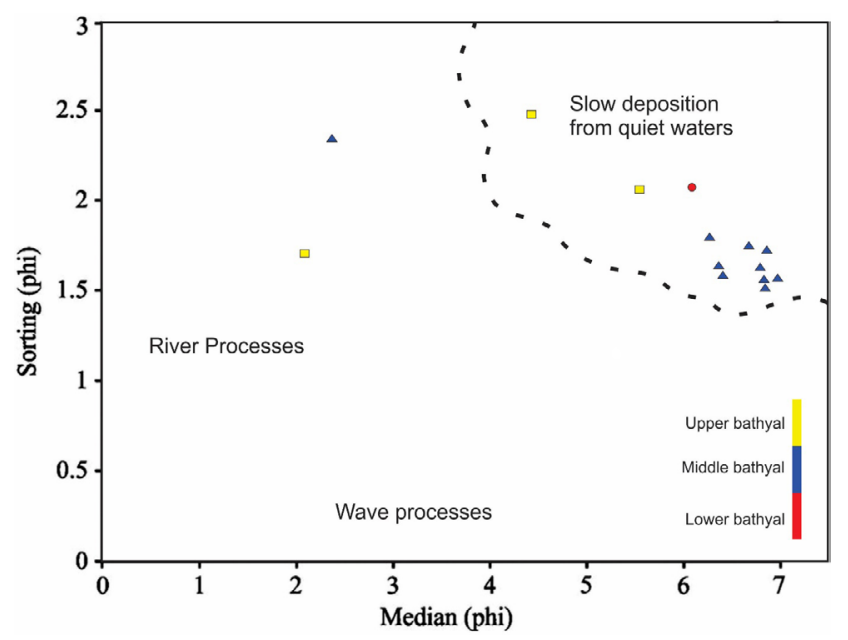

Figure 8: The Stewart diagram shows that majority of the sediments in the Simeulue sub-basin were deposited during a slow deposition process in quiet waters.

for relatively fine-sized sediments at deeper bathymetry. On the other hand, the Stewart diagram (Stewart, 1958) is used to describe the relationship between the median and sorting of phi values (see Figure 8) in the sub-basin to understand the sediment deposition process. Almost all sediments were deposited slowly in the quiet waters (see Figure 8). In accordance with the conditions of deposition that occurs in the deep sea, the sedimentation of fine-grained material occurs slowly under relatively quiet conditions.

\subsection{Geochemical element values}

Geochemical element traces are primarily used to understand the nature of the source from which the sediments are derived (Pettijohn, 1984) because the elements are sensitive to the mode of transportation, type of 


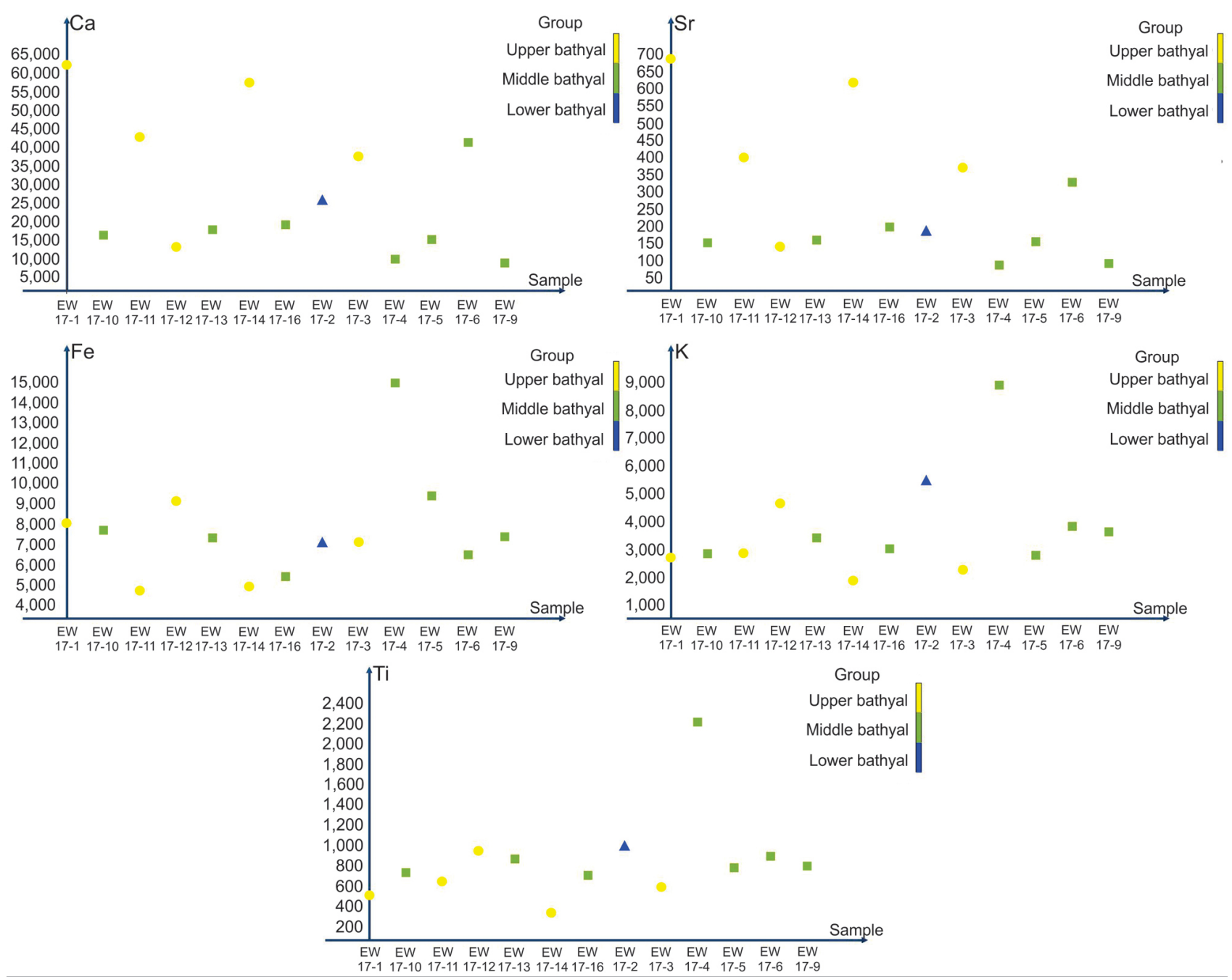

Figure 9: Geochemical element values in the Simeulue waters that described the origin of sediment sources.

weathering undergone, the distance transported, the period of stay and the nature of depositional basin. The distribution of elements is controlled by so many factors such as destruction by wear and tear, density, grain size water motion, and energy in the depositional environment. Based on the analysis using an XRF scanner, the chemical elements can describe the origin of sediment sources, such as Calcium (Ca), Strontium (Sr), Potassium (K), Iron (Fe) and Titanium (Ti) (see Figure 9). In general, high $\mathrm{Ca}$ and $\mathrm{Sr}$ content indicate a marine sediment source, and at the same time, $\mathrm{K}, \mathrm{Fe}$, Ti content indicates landward sources (Ritcher et al., 2006; Rothwell and Croudance, 2015; Zuraida et al., 2017). Generally, $\mathrm{Ca}$ content ranges from 9070.04 to 62458.68 ppm, Sr content between 88.19 and 689.72 ppm, K content lies within 1926.97 to $8932.29 \mathrm{ppm}, \mathrm{Fe}$ ranges between 4758.7 and $15004.21 \mathrm{ppm}$ and Ti content ranges from 344.82 to $2228.13 \mathrm{ppm}$. There is a clear general trend of geochemical values increasing as the bathymetry deepens. In the middle of the bathyal, there are almost high and varied content of geochemical elements, $\mathrm{Ca}$ content ranges from 9070.04 to $62458.68 \mathrm{ppm}, \mathrm{Sr}$ content between 88.19 and $689.72, \mathrm{~K}$ value ranges from 2324.87 - $8932.29 \mathrm{ppm}$, Ti content ranges from 522.2 $2228.13 \mathrm{ppm}$, and Fe contents lies between 5459.67 and $15004.21 \mathrm{ppm}$. On the other hand, in the upper bathyal, geochemical element values are lower than in the middle bathyal. Ca content ranges from 43058.8 to 57634.73 ppm, Sr content between 402.31 and 620.22, K content ranges from $1926.97-2907.63 \mathrm{ppm}$, Ti content ranges between $344.82-658.08$ ppm, and Fe content lies between 4758.7 and $4975.39 \mathrm{ppm}$.

\subsection{Principal component analysis (PCA)}

The PCA demonstrates the first two main components (axes) that describe $77.957 \%$ of the dispersion cloud of the point (see Table 4). This indicates the factorial plan of axes 1 and 2 interpreted $77.957 \%$ of the difference of the samples. As mentioned by Jolliffe (1986), the rule of cut off level on the eigenvalue should correspond to 0.7 times the mean of other principal components. The first two factorial axes (Principal Components 1 and 2) commonly combine most of the data variability (see Table 4), admitting the identification of the variable that best 
explains the case differentiation. Component 1 positively relates to the sorting, skewness, as well as $\mathrm{Ca}$ and $\mathrm{Sr}$ content. Conversely, sand percentages, kurtosis, skewness and depth are predicted to be negative with this component (see Figure 10). These components are the largest contributors to this component, up to $55.797 \%$ of data variability (see Table 4). Furthermore, Component 2 includes mud percentages, mean, median, and Fe, $\mathrm{K}$, Ti content, and they all have a positive correlation in this component. Component 2 accounts for $22.169 \%$ of the data variability. There was a clear influence of the percentage of finest sediments, mean and median.

\subsection{Cluster analysis}

The cluster analysis was performed through a data matrix comprising thirteen variables: bathymetry, sand percentage, mud percentage, mean grain size, standard deviation (sorting), skewness, kurtosis and median, content of $\mathrm{Ca}, \mathrm{Sr}, \mathrm{K}, \mathrm{Fe}$ and $\mathrm{Ti}$. The dendrogram cluster

Table 4: Principal component (axes) contribution

\begin{tabular}{|l|l|l|}
\hline & F1 & F2 \\
\hline Eigenvalue & 7.254 & 2.882 \\
\hline Variability (\%) & 55.797 & 22.169 \\
\hline Cumulative \% & 55.797 & 77.966 \\
\hline
\end{tabular}

analysis for thirteen variables from Simeulue sediments is presented in Figure 11 (a and b). Figure 11a shows sediment groups based on their respective characters subjected for separation. In this case, the distance is 7779 to create five classes with different characters (see Figure 11b): Class 1 (EW17-1, and EW17-14), Class 2 (EW17-2, EW17-5, EW17-9, EW17-10, EW17-12, EW17-13, and EW17-16), Class 3 (EW17-3, EW17-6, and EW17-11), Class 4 (EW17-4) and Class 5 (EW1715). This result reflects the similarities shared among samples from the Simeulue site, and note that the dendrogram has only one end-member-Class 5. This may indicate the similarities among the other sites, perhaps due to the limited range of sediment sources for the Class 5 environments. The differentiation of the sampling areas into two groups parallels the association of samples into groups on the basis of the bivariate plots of the statistical grain size parameters and the discrimination functions.

\subsection{Facies Distribution}

Based on the cluster analysis, the sedimentary facies in the Simeulue sub-basin were divided into five facies with similar sediment characteristics and depositional environments. The facies (see Table 5), are described as follows: Facies 1 has coarse grain, $41.2 \% \mathrm{mud}, 58.8 \%$

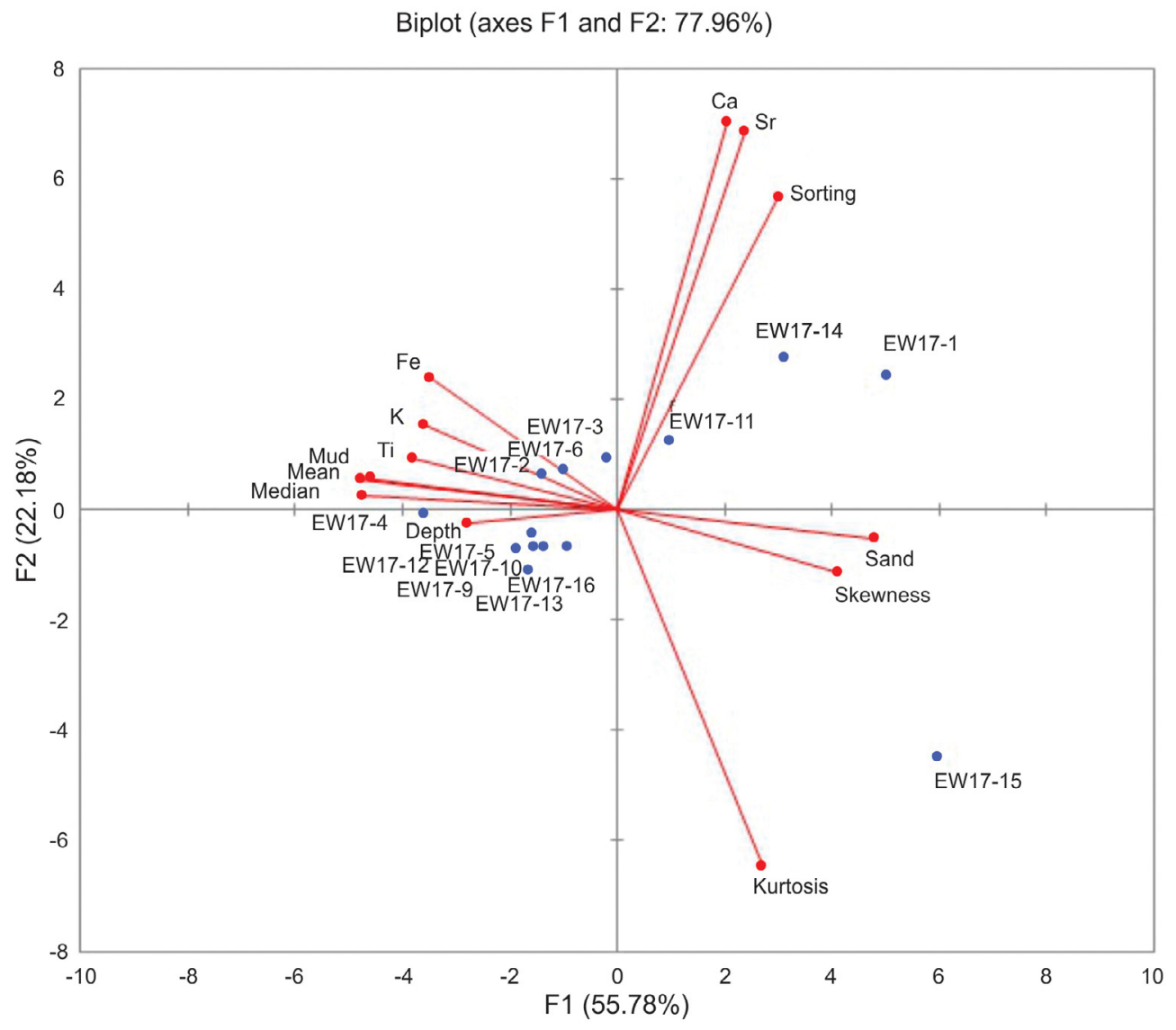

Figure 10: The PCA graph shows 16 samples classified into five groups and is influenced by two main factors 
A

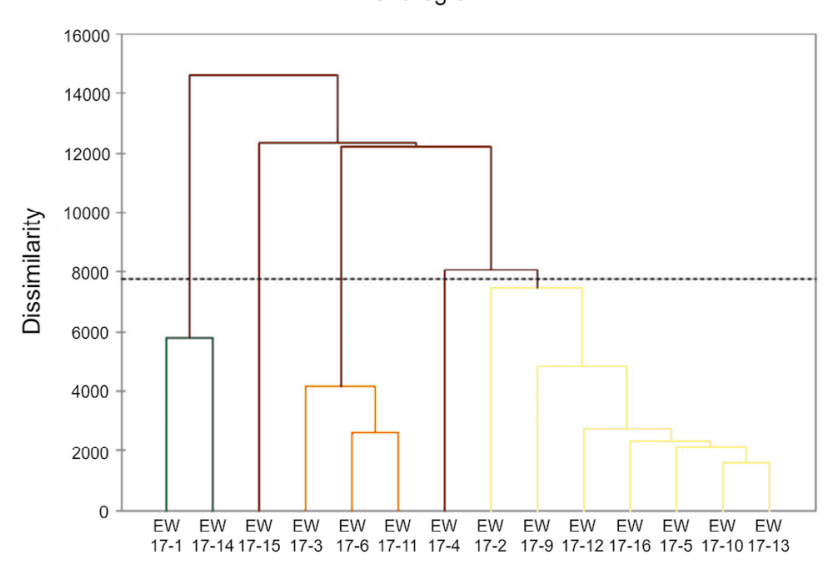

B

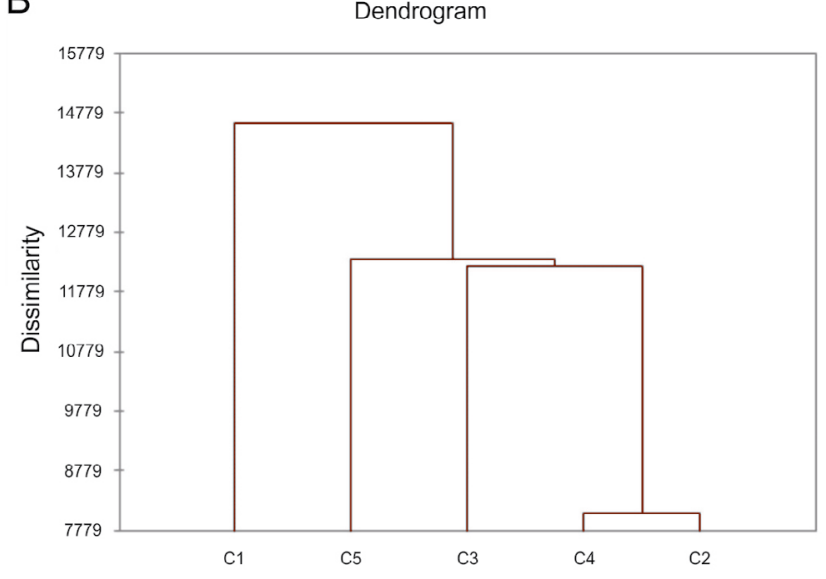

Figure 11: The dendrogram achieved from a single linkage cluster that grouped sediment in the Simeulue sub-basin into five facies.

sand, very poor sorting deposited in the upper bathyal. It indicates a high energy environment as it has a high value of kurtosis and skewness. The geochemical element showed the highest $\mathrm{Ca}$ and $\mathrm{Sr}$ values, whereas the lowest $\mathrm{K}, \mathrm{Ti}, \mathrm{Fe}$ values indicated the sediment originated in a marine environment. Facies 2 has fine grain (fine silt), $94.1 \%$ mud, $0.59 \%$ sand, poor sorting deposited in the middle bathyal at 1226.14 meters. It shows a low to medium energy environment as it has a high value of kurtosis and low skewness. This facies is a mixture of the sediments originating from marine and terrestrial environments indicated by the geochemical element values. Facies 3 has fine grain (medium silt), 87.8\% mud, 12.2\% sand, poor sorting deposited in the lower bathyal. It reflects a low to medium energy environment as it has a medium value of kurtosis and low skewness. This facies is also a mixture of the sediments originating from marine and terrestrial environments indicated by the geochemical element values. Facies 4 has fine grain (fine silt), $94.7 \%$ mud, $0.53 \%$ sand, poor sorting deposited in the middle bathyal. It indicates a low energy environment as it has a high value of kurtosis and skewness. The geochemical element showed the highest $\mathrm{K}, \mathrm{Ti}, \mathrm{Fe}$ values, on the other hand, the lowest $\mathrm{Ca}$ and $\mathrm{Sr}$ values indicated the sediment originated from a terrestrial environment and adjacent. Facies 5 has very coarse grain, 15.9\% mud, $84.1 \%$ sand, poor sorting deposited in the upper bathyal at 495 meters. It represents a high energy environment as it has a high value of kurtosis and skewness.

\section{Conclusions}

The characterization of sedimentology variables is the proper proxy to recognize the process of sediment deposition and indirectly demonstrates hydrodynamic energy. The observed variables in this study were grain size sediment and geochemical elements. Furthermore, these variables were calculated by a multivariate statistical analysis. As an effective method, the statistical anal-
Table 5. Data compilation of GSTA, bathymetry and geochemical for facies determination

\begin{tabular}{|c|c|c|c|c|c|}
\hline \multirow{2}{*}{$\begin{array}{l}\text { Characte- } \\
\text { ristics }\end{array}$} & \multicolumn{5}{|l|}{ Facies } \\
\hline & 1 & 2 & 3 & 4 & 5 \\
\hline Mean & 3.95 & 6.72 & 6.21 & 6.53 & 2.43 \\
\hline Sorting & 2.41 & 1.67 & 1.87 & 1.64 & $1.7 \mathrm{q}$ \\
\hline Skewness & 0.35 & 0.02 & 0.04 & 0.12 & 0.53 \\
\hline Kurtosis & 0.96 & 1.03 & 0.95 & 1.04 & 2.1 \\
\hline Median & 3.39 & 6.71 & 6.18 & 6.38 & 2.06 \\
\hline Mud & 0.41 & 0.94 & 0.88 & 0.95 & 0.16 \\
\hline Sand & 0.59 & 0.06 & 0.12 & 0.05 & 0.84 \\
\hline Depth & 473.5 & 1226.14 & 726.33 & 1505 & 495 \\
\hline $\mathrm{Ca}$ & 60046.71 & 16911.56 & 40794.33 & 10163.12 & 0 \\
\hline $\mathrm{Sr}$ & 654.97 & 156.69 & 368.32 & 88.19 & 0 \\
\hline $\mathrm{K}$ & 2340.46 & 3723.66 & 3032.21 & 8932.29 & 0 \\
\hline $\mathrm{Ti}$ & 433.51 & 844.07 & 723.78 & 2228.13 & 0 \\
\hline $\mathrm{Fe}$ & 6538.45 & 7683.23 & 6154.42 & 15004.21 & 0 \\
\hline
\end{tabular}

ysis was used to help determine a deposition pattern and to provide a clear description for classifying facies in the Simeulue sub-basin. The result of grain size analysis showed the domination of mud with poor sorting in the middle of the basin, while sediments near the islands were dominated by coarser sediments. The grain size is also correlated with the bathymetry condition. In general, the deeper bathymetry has a finer sediment. Depositional energy, illustrated in the bivariate graph, shows low to medium energy. This energy variation is correlated with bathymetry and textural sediment. It was supported by the CM and Stewart diagrams that the sediment was deposited with a slow pelagic suspension mechanism in quiet waters. At the same time, the result of geochemical element analysis showed high levels of $\mathrm{K}$, Ti and $\mathrm{Fe}$, which indicated the provenance of sediment from the mainland. Furthermore, the multivariate analysis obtained five facies that were determined based on their similar sedimentary characteristics, geochemi- 
cal elements, and the environment of sediment deposition. In general, facies characteristics in the upper bathyal were coarse sediment with the highest $\mathrm{Ca}$ and $\mathrm{Sr}$ content that indicate a marine environment as their source material. The facies in the middle bathyal characterized by the dominance of fine sediment and the $\mathrm{K}$, Ti, $\mathrm{Fe}$ values reached the highest content, which indicates the sediment originated from a terrestrial environment and adjacent. Another facies in the middle - lower bathyal characterized by fine sediment and the geochemical elements show a mixture of the sediments originating from marine and terrestrial environments. In the future, this study still needs to be developed in more detail and expects to be a modern facies analogue model that can be used in sedimentological studies for paleoclimate and paleoenvironmental research.

\section{Acknowledgment}

This research was funded in full or partially by the Indonesian government through the 'flagship' LIPI, Expedition of Widya Nusantara in the 2017 budget year. We would like to thank Dr. Dirhamsyah as a former director of the Research Centre for Oceanography, Indonesian Institute of Sciences (LIPI) for the opportunity to take part in the Widya Nusantara Expedition (EWIN) 2017. We would also like to thank Dr. Aan Johan Wahyudi as a coordinator of EWIN 2017, Nurul Fitriya M.Sc as a chief scientist, the captain, and crew of the Baruna Jaya VIII research vessel, all of the scientists and technicians who collaborated and helped in the EWIN 2017. We also would like to thank Singgih Prasetyo Adi Wibowo for his help in sampling during the expedition, Jakah for helping in XRF analysis, Tegar Maulana, Ragil Pratiwi, Rebbeca Santi as well as Steve Popple for the assistance in drafting and proofreading.

\section{References}

Allen, J.L., and Johnson, C.L. (2010): Facies control on sandstone composition (and influence of statistical methods on interpretation) in the John Henry Member, Straight Cliffs Formation, Southern Utah, USA. Sedimentary Geology, 230, 60-76.

Ashley, G.M. (1978): Interpretation of polymodal sediments. Journal of Geology, 86, 411-21.

Bascom, W.N. (1951): The relationship between sand-size and beach face slope. Transactions American Geophysical Union, 32, 866-874.

Blott, S.J., and Pye, K. (2001): GRADISTAT: A grain size distribution and statistics package for the analysis of unconsolidated sediments. Earth Surface Processes and Landforms, 26, 1237-1248.

Bobertz, B., and Harff, J. (2003): Sediment facies and hydrodynamic setting: A study in the south western Baltic Sea. Ocean Dynamics, 54, 39-48.

Boggs, S.J.R. (1995): Principles of Sedimentology and Stratigraphy. University of Oregon, Prentice Hall, New Jersey, $662 \mathrm{p}$.
Brouwer, P. (2010): Theory of XRF: Getting Acquainted with the Principles. PANalytical B.V, Almelo, the Netherlands, $59 \mathrm{p}$.

Chambers, R.L., and Upchurch, S.B. (1979): Multivariate analysis of sedimentary environments using grain-size frequency distributions. Mathematical Geology, 11, 27-43.

Croudace, I.W., and Rothwell, R.G. (2015): Micro-XRF Studies of Sediment Cores: Applications of a non-destructive tool for the environmental sciences, Developments in Paleoenvironmental Research, Springer, London, 17, 656 p.

Dickhudt, P.J., Friedrichs, C.T. and Sanford, L.P. (2011): Mud matrix solids fraction and bed erodibility in the York River, USA, and other muddy environments. Continental Shelf Research, 31, S3-S13.

Dypvik, H., and Harris, N.B. (2001): Geochemical facies analysis of fine-grained siliciclastics using $\mathrm{Th} / \mathrm{U}, \mathrm{Zr} / \mathrm{Rb}$ and $(\mathrm{Zr}+\mathrm{Rb}) / \mathrm{Sr}$ ratios. Chemical Geology, 181, 131-146.

Folk, R.L., and Ward, M.C. (1957): Brazos River bars: A study in the significance of grain size parameters. Journal of Sedimentary Petrology, 27, 3-27.

Francke, A., Wennrich, V., Sauerbrey, M, Juschus, O., Melles, M., and Brigham-Grette, J. (2013): Multivariate statistic and time series analyses of grain-size data in quaternary sediments of Lake El'gygytgyn, NE Russia. Climate of the Past, 9, 2459-2470.

Friedman, G.M. (1961): Distinction between dune, beach, and river sands from their textural characteristics. Journal of Sedimentary Petrology, 31, 514-529.

Friedman, G.M. (1979): Difference in size distributions of populations of particles among sands of various origins: Addendum to IAS presidential address. Sedimentology, 26, 859-862.

Gischler, E., and Lomando, A.J. (2005): Offshore sedimentary facies of a modern carbonate ramp, Kuwait, northwestern Arabian-Persian Gulf, Facies, 50, 443-462.

Gosseau, D. (2009): Introduction to XRF Spectroscopy. Plenum, New York, 56-63p.

Griffiths, J.C. (1967): Scientific Methods in the Analysis of Sediments. McGraw-Hill, New York, 508 p.

Hemming, S.R., van de Flierdt, T., Goldstein, S.L., Franzese, A.M., Roy, M., Gastineau, G., and Landrot, G. (2007): Strontium isotope tracing of terrigenous sediment dispersal in the Antarctic Circumpolar Current: Implications for constraining frontal positions, Geochemistry Geophysics Geosystems, 8, Q06N13.

Irzon, R. (2018): Geochemical character of coastal sediments from Southern Kulon Progo with implications for provenance. Jurnal Geologi dan Sumberdaya Mineral, 19, 31-45.

Johnson, R.A., and Wichern, D.W. (2007): Applied multivariate statistical analysis (6th Ed). Prentice International Inc., New Jersey, 773 p.

Jolliffe, I.T. (1986): Principal component analysis. Springer, New York, 487 p.

Jongman, R.H.G., Ter Braak, C.J.F. and van Tongeren, O.F.R. (1995): Data analysis in community and landscape ecology. Centre for Agricultural Publishing and Documentation (Pudoc), Wageningen, 299 p. 
Journel, A. G. (1983): Nonparametric estimation of spatial distributions. Journal of the International Association for Mathematical Geology, 15, 445-468.

Langer, M.R. (2008): Assessing the Contribution of Foraminiferan Protists to Global Ocean Carbonate Production. Journal Eukaryot Microbiology, 55, 163-169.

Martins, L.R, Potter, P.E., Martins, I.R and Wolff, I.M. (1997): Grain-size and modern sedimentary environments. Congreso Latinoamericano de Sedimentologia, 1u Memorias II, 67-71.

McCave, I. N. (1984). Erosion, transport and deposition of fine-grained marine sediments. Geological Society London Special Publications, 15, 1, 35-69.

McClaren, P. and Bowles, D. (1984): The Effects of Sediment Transport on Grain-Size Distributions. Journal of Sedimentary Petrology, 55, 457-470.

Medina, R., Losada, M.A, Losada, I.J. and Vidal, C. (1994): Temporal and spatial relationship between sediment grainsize and beach profile. Marine Geology, 118, 195-206.

Nesbitt, H.W., Markovics, G., and Price, R.C. (1980): Chemical processes affecting alkalis and alkaline earths during continental weathering. Geochemica et Cosmochimica Acta, 44, 1659-1666.

Nosrati, K., and van Den Eeckhaut, M. (2012): Assessment of groundwater quality using multivariate statistical techniques in Hashtgerd Plain, Iran. Environmental Earth Sciences, 65, 1, 331-344.

Nugroho, S.H., and Basit, A. (2014): Sediment distribution based on grain size analyses in Weda Bay, Northern Maluku. Jurnal Ilmu dan Teknologi Kelautan Tropis, 6, 229-240.

Nugroho, S.H., and Putra, P.S. (2018): Spatial Distribution of Grain Size and Depositional Process in Tidal Area along Waikelo Beach, Sumba. Marine Georesources and Geotechnology, 36, 3, 299-307.

Nugroho, S.H., Putra, P.S., Yulianto, E. and Noeradi, D. (2018): Multivariate statistical analysis for characterization of sedimentary facies of Tarakan sub-basin, North Kalimantan. Marine Georesources \& Geotechnology, 36, 8, 907-917.

Nugroho, S.H., and Putra, P.S. (2019): Characteristics of Grain Size Distribution on Beaches Sediment of Sumba Island, Nusa Tenggara Timur Based on Grainsize and Geochemical Data. Jurnal Geologi dan Sumberdaya Mineral, 20, 3, 153-164.

Oyedotun, T.D.T., Burningham, H. and French, J.R. (2012): Characterisation of estuary and adjacent beach sediments in the Gannel Estuary, South-West England. Geoscience in South-West England, 13, 71-76.

Passega, R. (1964): Grain size representation by CM patterns as a geological tool. Journal of Sedimentary Petrology, 34, $830-847$

Poppe, L.J., and Eliason, A.H. (2008): A Visual Basic program to plot sediment grain-size data on ternary diagrams. Computers and geosciences, 34, 5, 561-565.

Putra, P. S., and Nugroho, S.H. (2017): Subsurface Sediment Distribution in the Sumba Waters, East Nusa Tenggara. Oseanologi dan Limnologi di Indonesia, 2, 3, 49-63.
Putri, M.R., Bernawis, L.I., Fadli, M., and Anwar, I.P. (2017): Pengaruh Awal Musim Dingin Asia Terhadap Dinamika Perairan Barat Sumatra Bagian Utara [Influences of Asia Winter Monsoon Onset on Ocean Dynamic in the Northern Part of West Sumatra]. Laporan Hasil Ekspedisi Widya Nusantara (EWIN) 2017 Tim Oseanografi, 20 p. (in Indonesian language)

Richter, T.O., van der Gaast, S., Koster, B., Vaars, A., Gieles, R., de Stigter,H.C., de Haas, H., and van Weering, T.C.E. (2006): The Avaatech XRF Core Scanner: Technical Description and Applications to NE Atlantic Sediments. In: G. Rothwell (ed): New Techniques in Sediment Core Analysis. Special Publications Geological Society, 39-50, 267 p.

Rothwell, R.G. and Croudace, I.W. (2015): Twenty Years of XRF Core Scanning Marine Sediments: What Do Geochemical Proxies Tell Us? In: Croudace, I.W., and Rothwell, R.G. (eds.): Micro-XRF Studies of Sediment Cores: Applications of a Non-Destructive Tool for the Environmental Sciences. Development in Paleoenvironmental Research 17. Springer, pp. 25-102.

Sampurno, P., Zuraida, R., Nurdin, N., Gustiantini, L. and Aryanto, N.C.D. (2018): Elemental Analysis on Marine Sediments Related to Depositional Environment of Bangka Strait. Bulletin of the Marine Geology, 32, 2, 89-96.

Sidjabat, M.M. (1974): Pengantar Oseanografi. Bogor: Institut Pertanian Bogor, Bogor, 121 p. (in Indonesian language)

Stewart, H.B. (1958): Sedimentary reflections of depositional environments in San Miguel Lagoon, Baja California, Mexico. American Association of Petroleum Geologists Bulletin, 42, 2567-2618.

Surinati, D. (2009): Physical Oceanographic Condition of the Western Waters of Sumatera (Simeulue Island Water) on August 2007 Pasca Tsunami December 2004. Makara Journal of Science, 13, 1, 17-22.

Syvitski, J.P.M. (1991): Factor analysis for size frequency distribution: significance of factor solutions based on simulation experiments. In Syvitski, J.P.M. (ed): Principles, methods and application of particle size analysis, Cambridge University Press, New York, 249-263, 368 p.

Thoms, M.C., Parsons, M.E and Foster, J.M. (2007): The use of multivariate statistics to elucidate patterns of floodplain sedimentation at different spatial scales. Earth Surface Processes and Landforms, 32, 672-686.

Tipsword, H.L., Setzer, F.M. and Smith, F.M. (1966): Interpretation of depositional environment in Gulf Coast petroleum exploration from paleoecology and related stratigraphy. Transactions of the Gulf Coast Association of Geological Societies, 16, 119-30

Tucker, M.E. (1988): Techniques in Sedimentology. Blackwell Scientific Publications Ltd., Oxford, UK, 394 p.

Visher, G.S. (1969): Grain size distribution and depositional process. Journal of Sedimentary Research, 39, 1074-1106.

Wachecka-Kotkowska, L., and Kotkowski, P. (2011): Grainsize distribution analysis of Quaternary sediments from the southern part of the Lodz region in Poland: A computational-methods approach. Geologos, 17, 205-219.

Wisha, U. J., Gemilang, W.A., Rahmawan, G.A. and Kusumah, G. (2017): Distribution patterns of bottom sedi- 
ment based from morphological and hydro-oceanography characteristics using interpolation and numerical simulation model in Simeuluecut Island Northern waters. Jurnal Kelautan: Indonesian Journal of Marine Science and Technology, 10, 1, 29-40.

Wyrtki, K. (1961): Scientific results of marine investigations of the South China Sea and the Gulf of Thailand 19591961. Naga Report, Vol. 2, University of California, San Diego, 195 p.
Yim, O., and Ramdeen, K.T. (2015): Hierarchical cluster analysis: comparison of three linkage measures and application to psychological data. The quantitative methods for psychology, 11, 1, 8-21.

Zuraida, R., Gerhaneu, N.Y. and Sulistyawan, I.H. (2017): Coastal and surfacial sediment characteristics on Papela Bay, Rote District, East Nusa Tenggara Province. Jurnal Geologi Kelautan, 15, 2, 81-94.

\section{SAŽETAK}

\section{Određivanje teksture i geokemijskih obilježja elemenata taložina morskoga dna uporabom multivarijantne analize, podbazen Simeulue, Indonezija}

Podbazen Simeulue nalazi se uz sjeverozapadni rub Sumatre, između vanjskoga luka i kopna. Taložna i geokemijska obilježja bazena važne su sedimentološke varijable u prepoznavanju taložnih procesa. Te varijable u analiziranome prostoru do sada nisu bile dobro proučene. Stoga su istražene u ovome radu te je napravljena njihova razdioba kako bi se utvrdili taložni facijesi u tome podbazenu. Uzorci su uzeti na različitim dubinama tijekom ekspedicije „Widya Nusantara” 2017. godine, obavljene istraživačkim brodom Baruna Jaya VIII. Analiza trenda veličine zrna pokazala je kako u srednjemu dijelu bazena prevladava mulj, dok je na rubovima, u blizini kopna (otoka Sumatre) istaložen krupniji detritus. Geokemijska analiza načinjena je na svakome pojedinačnom uzorku s ciljem određivanja njegova podrijetla. Rezultati su naknadno analizirani multivarijantnom statistikom koja je odabrana kao najprimjereniji alat za određivanje taložnih facijesa i okoliša. Temeljem takve analize podbazen Simeulue podijeljen je u pet taložnih facijesa sa sličnim svojstvima taložina. Taložni okoliš bio je sličan, niskoenergijski do srednjoenergijski.

\section{Ključne riječi:}

taložine, veličina zrna, geokemija, multivarijantna analiza, Simeulue

\section{Author's contribution}

Septriono Hari Nugroho (1) (M.Sc, junior researcher, quaternary geologist, sedimentologist) as the main contributor provided the grain size and geochemical analysis, statistical analysis, palaeoenvironmental interpretations and presentation of the results. Purna Sulastya Putra (2) (M.Sc, senior researcher, quaternary geologist, sedimentologist) performed the field work, contributing with the geology of the Simeulue sub-basin and providing some references as well as editing the manuscript. 